\title{
PENERAPAN MODEL PEMBELAJARAN VAN HIELE UNTUK MENINGKATKAN HASIL BELAJAR SISWA PADA MATERI LUAS PERMUKAAN SERTA VOLUME BALOK DAN KUBUS DI KELAS VIII SMP NEGERI 18 PALU
}

\author{
Hernita Rancendo ${ }^{1)}$, Abdul Hamid ${ }^{2)}$, Marinus B. Tandiayuk ${ }^{3)}$ \\ hernitarancendo@gmail.com ${ }^{1)}$,abdulhamid@yahoo.com ${ }^{2}$, marinustandiayuk@yahoo.com ${ }^{3)}$
}

\begin{abstract}
Abstrak:Tujuan penelitan ini adalah untuk mendeskripsikan penerapan model Pembelajaran Van Hiele untuk meningkatkan hasil belajar siswa pada materi Luas Permukaan serta Volume Balok dan Kubus di kelas VIII SMP N 18 Palu. Rancangan penelitian mengacu pada model Kemmis dan Mc.Taggart, yang terdiri dari 4 komponen yaitu: 1) perencanaan, 2) tindakan, 3) pengamatan, dan 4) refleksi. Subjek penelitian ini ialah siswa kelas VIII SMP N 18 Palu yang berjumlah 20 siswa. Teknik pengumpulan data dalam penelitian ini yaitu observasi, tes, wawancara, dan catatan lapangan. Hasil penelitian menunjukkan bahwa penerapan model pembelajaran Van Hiele dapat meningkatkan hasil belajar siswa dengan mengikuti fase-fase: 1) informasi, 2) orientasi terarah, 3) uraian, 4) orientasi bebas, dan 5) integrasi.
\end{abstract}

Kata Kunci: model Pembelajaran Van Hiele, Hasil Belajar, Luas Permukaan serta Volume Balok dan Kubus.

\begin{abstract}
The purpose of this research is to describe the application of Van Hiele Learning model to improve student learning outcomes on Surface Surface and Block and Cube in Grade VIII SMP N 18 Palu. The study design refers to the Kemmis and Mc.Taggart model, which consists of 4 components: 1) planning, 2) action, 3) observation, and 4) reflection. The subject of this research is the students of class VIII SMP N 18 Palu, amounting to 20 students. Data collection techniques in this study are observation, tests, interviews, and field notes. The results showed that the application of Van Hiele learning model can improve student learning outcomes by following the phases: 1) information, 2) orientation directed, 3) description, 4) free orientation, and 5) integration.
\end{abstract}

Keywords: Van Hiele Learning model, Learning Outcomes, Surface Area and Volume of Beams and Cubes.

Matematika merupakan salah satu ilmu yang mendasari perkembangan ilmu pengetahuan, teknologi dan seni dan selalu memiliki peran penting pada berbagai disiplin ilmu pengetahuan. Oleh karena itu, pembelajaran matematika perlu diberikan kepada seluruh peserta didik mulai dari jenjang pendidikan prasekolah sampai dengan sekolah menengah, bahkan hingga perguruan tinggi. Melalui matematika peserta didik akan memiliki kemampuan berpikir logis, analisis, sistematis, kritis dan kreatif serta kemampuan bekerjasama (Depdiknas, 2006:2). Selain itu, dengan kemampuan berpikir logis peserta didik akan mampu tampil sebagai generasi bangsa yang berkualitas dalam menghadapi fenomena kehidupan yang selalu berubah, menantang dan kompetitif.

Berdasarkan hasil diskusi peneliti dengan guru bidang studi matematika di SMP Negeri 18 Palu diperoleh informasi bahwa masih banyak siswa yang mengalami kesulitan pada materi luas permukaan serta volume balok dan kubus. Kegiatan pembelajarannya guru cenderung menggunakan model pembelajaran konvensional, yakni model pembelajaran yang berpusat pada guru dan lebih mengutamakan hafalan daripada pengertian serta 
mengutamakan hasil daripada proses. Hal tersebut tentunya akan menghambat kemampuan siswa dalam belajar geometri.

Salah satu upaya yang dapat dilakukan untuk mengatasi permasalahan tersebut adalah dengan menerapkan suatu pembelajaran yang dapat memberikan kesempatan kepada siswa untuk mengkonstruksi sendiri pengetahuannya dalam mempelajari geometri. Menurut Thohari (2010) model pembelajaran Van Hiele adalah salah satu model pembelajaran yang cocok digunakan pada materi geometri karena selain memberikan kesempatan kepada siswa untuk mengkontruksi sendiri pengetahuannya, model pembelajaran Van Hiele juga dapat merespon kebutuhan siswa semua yang mungkin bervariasi dalam tingkat berpikir dan kemampuan geometrinya. Hal ini dikarenakan model pembelajaran Van Hiele memiliki 5 fase perkembangan berpikir dalam belajar geometri, yaitu fase 1 (Inkuiri/Informasi), fase 2 (Directed Orientation/Orientasi Terarah), fase 3 (Explication/Uraian), fase 4 (Free Orientation/Orientasi Bebas), fase 5 (Integration/Integrasi). Dengan menetapkan model pembelajaran Van Hiele diharapkan siswa dapat memahami dengan benar materi luas permukaan serta volume balok dan kubus.

Hasil penelitian yang relevan dengan penelitian ini yaitu hasil penelitian Yadil (2009) menyimpulkan bahwa ternyata scenario pembelajaran model Van Hiele yang digunakan dalam pembelajaran pada pokok bangun-bangun segiempat dapat meningkatkan pemahaman siswa. Hasil penelitian Atik (2012) membuktikan dalam penelitiannya bahwa hasil belajar siswa sesudah diberikan perlakuan penerapan model pembelajaran Van Hiele mempunyai rata-rata hitung (mean) lebih tinggi dari pada hasil belajar siswa sebelum diberlakukan penerapan model pembelajaran Van Hiele. Berdasarkan hasil tersebut maka dapat disimpulkan bahwa model pembelajaran Van Hiele efektif terhadap hasil belajar matematika bagi siswa kelas V SD Negeri Bringin 01 Kecamatan Bringin Kabupaten Semarang Semester II Tahun Pembelajaran 2011/2012. Hasil penelitian Susanti (2011) bahwa penggunaan model pembelajaran Van Hiele dengan alat peraga efektif digunakan untuk menigkatkan hasil belajar peserta didik pada materi pokok bangun ruang sisi datar di Kelas VII MTs Darussalam Kroya. Hasil penelitian Julius (2011) menyimpulkan bahwa pada pembelajaran matematika geometri khususnya bangun datar segitiga, kesulitankesulitan yang ditemui dalam proses pembelajaran maupun pada hasil pembelajarannya dapat diatasi dengan menerapkan teori Van Hiele. Penerapan teori Van Hiele juga tidak menutup kemungkinan untuk mengkolaborasikan metode-metode yang lain yang dinilai dapat membantu proses pembelajaran.

Rumusan masalah pada penelitian ini adalah bagaimana penerapan model pembelajaran Van Hiele untuk meningkatkan hasil belajar siswa pada materi luas permukaan serta volume balok dan kubus di kelas VIII SMP Negeri 18 Palu?

\section{METODE PENELITIAN}

Desain penelitian ini mengacu pada model penelitian tindakan kelas yang dikembangkan oleh Kemmis dan Me Taggart (Depdikbud, 1999:21) yang terdiri atas empat komponen yaitu planning (perencanaan), acting (tindakan), observing (pengamatan) dan reflecting (refleksi).

Penelitian ini dilaksanakan di kelas VIII SMP Negeri 18 Palu. Subjek dalam penelitian ini adalah seluruh siswa kelas VIII yang terdaftar pada tahun ajaran 2017/2018 berjumlah 20 siswa. 
Teknik pengumpulan data pada penelitian ini yaitu berupa data observasi, wawancara, catatan lapangan dan tes tertulis. Analisis data mengacu pada model Miles dan Huberman (Sugiyono, 2007:246-252), yaitu (1) mereduksi data, (2) penyajian data, dan (3) penarikan kesimpulan.

Kriteria keberhasilan tindakan pada kegiatan penelitian ini ditentukan oleh dua hal, yaitu kriteria berdasarkan aktivitas guru dan siswa dalam pembelajaran dinyatakan berhasil apabila kualitas proses pembelajaran untuk setiap aspek yang dinilai berada dalam kategori baik atau sangat baik. Hasil belajar siswa setelah mengikuti pembelajaran dengan menerapkan model pembelajaran Van Hiele mencapai nilai 75, dan dikatakan tuntas secara klasikal apabila mencapai $75 \%$.

\section{HASIL PENELITIAN}

Hasil penelitian ini terdiri dari dua bagian, yaitu hasil pra tindakan dan pelaksanaan tindakan. Pada pelaksanaan pra tindakan, peneliti memberikan tes awal mengenai materi prasyarat yaitu definisi dan sifat-sifat bilangan berpangkat dengan tujuan untuk mengetahui kemampuan awal siswa dan membentuk kelompok yang heterogen. Tes ini diikuti oleh seluruh siswa kelas VIII SMP Negeri 18 Palu yang berjumlah 20 siswa. Berdasarkan hasil analisis tes awal diperoleh bahwa dari 20 orang siswa yang mengikuti tes tersebut, terdapat 12 orang siswa yang mencapai nilai ketuntasan sedangkan 8 orang siswa tidak tuntas. Hal ini menunjukan bahwa pemahaman siswa mengenai materi prasyarat masih rendah sehingga tidak mencapai ketuntasan yang telah diharapkan. Berdasarkan hasil tes awal dan hasil konsultasi peneliti dengan guru mata pelajaran matematika peneliti menentukan informan sebanyak 3 orang. Tiga informan yang terpilih yaitu (IKJ), (SH), dan (IN). Karakteristik informan yaitu IKJ berkemampuan tinggi, SH berkemampuan sedang, dan IN berkemampuan rendah. Tujuan peneliti mengambil informan dengan tingkat kemampuan akademik yang berbeda-beda karena dari masing-masing siswa tersebut akan diperoleh banyak informasi tentang kesulitan yang mereka hadapi dalam mengikuti pelajaran.

Pelaksanaan tindakan ini terdiri dari dua siklus dengan setiap siklus dilaksanakan dalam dua kali pertemuan. Pertemuan pertama pada masing-masing siklus membahas tentang materi yang akan dipelajari yaitu materi luas permukaan balok dan kubus pada siklus I dan materi volume balok dan kubus pada siklus II. Pertemuan kedua pada masingmasing siklus adalah memberikan tes akhir tindakan.

Proses pelaksanaan pembelajaran siklus I dan siklus II, dilaksanakan sesuai dengan rencana pelaksanaan pembelajaran yang terdiri atas kegiatan pendahuluan, inti dan penutup. Kegiatan tersebut bersesuaian dengan langkah-langkah model pembelajaran Van Hiele. Adapun langkah-langkah model pembelajaran Van Hiele yang digunakan terdiri dari lima fase, yaitu fase informasi (information), fase orientasi terarah (directed orientation), fase uraian (explication), fase orientasi bebas (free orientation), dan fase integrasi (integration).

Kegiatan awal pada setiap siklus yaitu peneliti memulai pembelajaran dengan mengucapkan salam, mengajak siswa untuk berdoa, dan mengecek kehadiran siswa. Siswa yang hadir pada pertemuan pertama setiap siklus yaitu sebanyak 20 siswa. Selanjutnya peneliti menyampaikan materi yang akan dipelajari. Materi yang dipelajari pada siklus I yaitu luas permukaan balok dan kubus, sedangkan pada siklus II mengenai materi volume balok dan kubus. Selanjutnya peneliti menyampaikan tujuan pembelajaran yang akan dicapai. Tujuan pembelajaran pada siklus I yaitu siswa dapat menentukan luas permukaan balok dan kubus, sedangkan tujuan pembelajaran pada siklus II yaitu siswa dapat 
menemukan rumus volume balok dan kubus. Setelah tujuan pembelajaran disampaikan, siswa menjadi tahu tujuan dari kegiatan pembelajaran dan terarah dalam belajar.

Kegiatan inti menerapkan fase-fase model pembelajaran Van Hiele yang terdiri atas 1) informasi, 2) orientasi terarah, 3) uraian, 4) orientasi bebas, dan 5) integrasi. Kegiatan yang dilakukan pada fase informasi yaitu peneliti menjelaskan tentang fase-fase model pembelajaran Van Hiele yang diterapkan dalam pembelajaran. Reaksi siswa pada siklus I adalah siswa masih kebingungan karena model pembelajaran Van Hiele merupakan model pembelajaran yang baru bagi mereka, sedangkan pada siklus II siswa sudah memahami model pembelajaran yang diterapkan.

Selanjutnya peneliti melaksanakan langkah ke dua yaitu orientasi terarah. Pada langkah ini, peneliti mengarahkan siswa untuk membentuk kelompok belajar yang terdiri dari 4-5 orang. Selanjutnya peneliti memberikan penjelasan mengenai Lembar Kerja Siswa (LKS) dan menekankan kepada siswa agar terlibat aktif dalam kelompoknya. Selama proses pengerjaan LKS berlangsung pada siklus I, peneliti memantau seluruh siswa dan menjadi fasilitator bagi siswa jika mengalami kesulitan. Sebagian siswa mengalami kesulitan sehingga peneliti membantu siswa dalam mengerjakan LKS dengan cara memberikan contoh luas permukaan balok dan kubus, sedangkan pada siklus II, siswa memahami permasalahan yang disajikan dalam LKS tentang materi volume balok dan kubus. Kondisi siswa menunjukkan kerjasama yang baik dalam kelompok dan berani bertanya kepada peneliti.

Kegiatan yang dilakukan pada fase uraian yaitu peneliti meminta masing-masing perwakilan kelompok mempresentasikan hasil kerja kelompoknya di depan kelas. Selanjutnya peneliti mengajak siswa untuk mengungkapkan ide-idenya dengan menggunakan bahasa mereka dan mendiskusikan jawaban yang telah dipresentasikan. Capaian siswa pada fase uraian yaitu siswa secara aktif mengungkapkan ide-idenya melalui diskusi kelompok.

Aktivitas pada fase orientasi bebas yakni peneliti memberikan tes individu kepada seluruh siswa dan mengawasi agar mereka tetap aktif mengerjakan soal masing-masing. Selama proses pengerjaan tes individu berlangsung peneliti memantau seluruh siswa dan menjadi fasilitator bagi siswa jika mengalami kesulitan. Siswa memperoleh pengalaman langsung dalam menyelesaikan soal secara mandiri.

Kegiatan pada fase integrasi yaitu peneliti mengajak siswa membuat rangkuman secara tertulis. Selanjutnya dengan bimbingan peneliti bersama-sama menyimpulkan mengenai materi yang telah dipelajari. Peneliti membimbing siswa menyimpulkan materi tentang luas permukaan balok dan kubus pada siklus I. Selanjutnya siklus II peneliti membimbing siswa menyimpulkan materi tentang volume balok dan kubus. Kondisi siswa pada fase integrasi yaitu siswa mampu menyimpulkan materi yang telah dipelajari.

Aktivitas kegiatan akhir yaitu peneliti meminta siswa untuk mempelajari kembali materi luas permukaan pada balok dan kubus. Peneliti menyampaikan kepada siswa bahwa akan memberikan tes akhir siklus I pada pertemuan berikutnya. Peneliti meminta siswa berdoa bersama. Kemudian setelah berdoa, peneliti mengakhiri pembelajaran dengan mengucapkan salam.

Pertemuan kedua dari setiap siklus yaitu peneliti memberikan tes akhir tindakan. Hasil tes yang diperoleh pada siklus I yaitu dari 20 siswa yang mengikuti tes, 12 siswa tuntas dan 8 siswa tidak tuntas. Tes akhir tindakan pada siklus I terdiri atas 4 nomor soal. Salah satu soal yang diberikan yaitu : hitunglah luas permukaan balok yang memiliki ukuran panjang $13 \mathrm{~cm}$, lebar $11 \mathrm{~cm}$, dan tinggi $9 \mathrm{~cm}$, ubahlah satuan hitung luas 
permukaannya kedalam satuan $d m^{2}$. Hasil jawaban salah satu siswa saat mengerjakan soal ditunjukan pada Gambar 1.

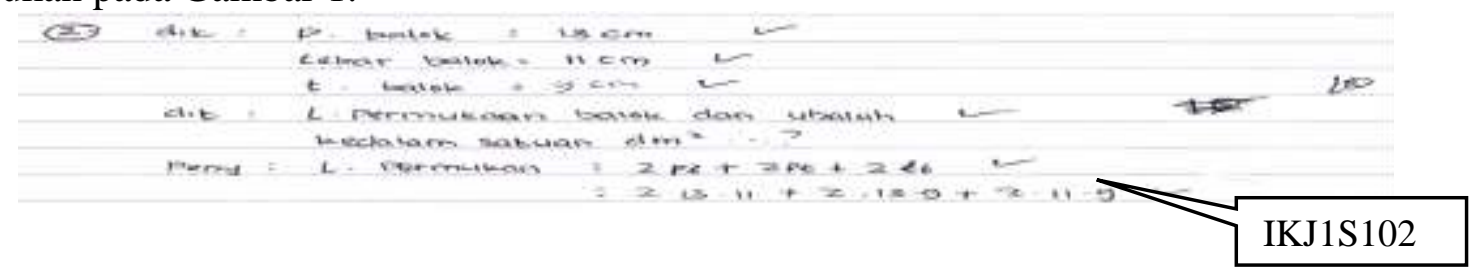

Gambar 1: Jawaban IKJ Pada Tes Akhir Tindakan Siklus I Nomor 2

Berdasarkan Gambar 1, siswa IKJ sudah memahami cara menyelesaikan soal menghitung luas permukaan namun dalam soal ini IKJ tidak menyelesaikannya. Ini menyebabkan IKJ kesulitan ketika mencari nilai akhirnya, karena IKJ kurang teliti. Setelah memeriksa hasil tes akhir tindakan, peneliti melakukan wawancara sebagaimana kutipan wawancara berikut.

IKJ S1 009 P : Pada saat mengerjakan tes akhir, susah tidak?

IKJ S1 $010 \mathrm{~S}$ : Lumayan kak.

IKJ S1 $011 \mathrm{P}$ : Bagaimana dengan hasil tesmu?

IKJ S1 $012 \mathrm{~S}$ : Lumayan bagus kak.

IKJ S1 $013 \mathrm{P}$ : Sekarang IKJ lihat jawaban nomor 2. Sudah tahu dimana letak kesalahanmu?

IKJ S1 014 S : Iya kak. Sudah tahu. Saya tidak menyelesaikan jawaban saya.

IKJ S1 015 P : Kenapa bisa?

IKJ S1 $016 \mathrm{~S}$ : Saya hanya fokus ke soal yang lain dan tidak cukup waktu lagi untuk menyelasaikannya.

IKJ S1 017 P : Jadi lain kali IKJ harus lebih teliti. Sering-sering kerjakan soal latihan. Dalam ujian nanti usahakan kerjakan soal dengan teliti. OK

IKJ S1 $018 \mathrm{~S}$ : Oke kak.

IKJ S1 019 P : $\quad$ Iya. Terimakasih waktunya IKJ, sudah bersedia kakak wawancarai.

IKJ S1 020 S : Sama-sama kak.

Pertemuan kedua dari setiap siklus yaitu peneliti memberikan tes akhir tindakan. Hasil tes yang diperoleh pada siklus II yaitu dari 20 siswa yang mengikuti tes, 15 tuntas dan 5 siswa tidak tuntas. Tes akhir tindakan pada siklus II terdiri atas 4 nomor soal. Salah satu soal yang diberikan yaitu : sebuah peti berbentuk kubus memiliki panjang rusuk $8 \mathrm{~cm}$. Jika peti tersebut diisi oleh peti kecil yang memiliki panjang rusuk $2 \mathrm{~cm}$, berapa banyak peti kecil yang harus diisi untuk memenuhi peti yang lebih besar tersebut ? Hasil jawaban salah satu siswa saat mengerjakan soal ditunjukan pada Gambar 2.

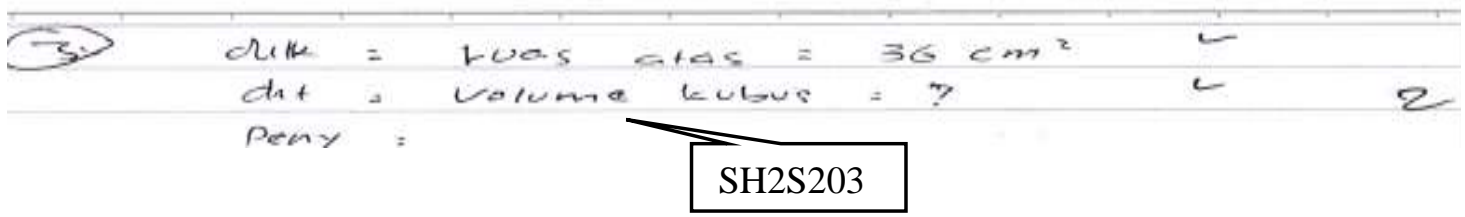

Gambar 2: Jawaban SH Pada Tes Akhir Tindakan Siklus II Nomor 3

Berdasarkan Gambar 2 terlihat bahwa SH sudah memahami cara menyelesaikan soal mengenai volume kubus hanya saja saat mengerjakan SH tidak menyelesaikan jawabannya. 
SH hanya menuliskan yang diketahui dan ditanyakan. Setelah memeriksa hasil tes akhir tindakan, peneliti melakukan wawancara sebagaimana kutipan wawancara berikut.

SH S2 007 P : Sudah lihat hasil tesmu?

SH S2 008 S : Sudah kak.

SH S2 009 P : Perhatikan jawabanmu nomor 3, SH sudah tahu letak kesalahannya?

SH S2 010 S : Iya kak sudah tahu, kesalahannya saya tidak menyelesaikan jawabanku, saya hanya menuliskan diketahui dan ditanyakan saja.

SH S2 011 P : Kenapa bisa SH tidak menyelesaikannya?

SH S2 012 S : $\quad$ Saya lupa rumus volume kubus kak.

SH S2 013 P : Jadi SH tidak mengerjakan soal nomor 3 karena lupa rumusnya ya?

SH S2 $014 \mathrm{~S}$ : $\quad$ Iya kak.

SH S2 015 P : Kenapa SH tidak bertanya pada kakak saat SH mengalami kesulitan?

SH S2 016 S : Saya malu kak.

SH S2 017 P : Kenapa meski malu? Lain kali SH kalau tidak tahu tanya ya supaya kakak bisa membantu $\mathrm{SH}$.

SH S2 018 S : Iya kak.

SH S2 019 P : lain kali SH kalau masih bingung dan belum paham harus berani bertanya dan harus lebih teliti lagi dan sering-sering latihan soal.

SH S2 $020 \mathrm{~S}: \quad$ Iya kak.

SH S2 021 P : Trimakasih SH karena sudah bersedia diwawancarai.

SH S2 022 S : Iya sama-sama kak.

Observasi dilaksanakan dengan menggunakan lembar observasi aktivitas guru dan lembar aktivitas siswa. Observasi ini bertujuan untuk mengumpulkan data dari aktivitas peneliti sebagai guru dan aktivitas siswa selama pembelajaran yang menerapkan model pembelajaran Van Hiele.

Aspek-aspek aktivitas guru yang diamati meliputi:1). guru memberi salam dan mengajak siswa untuk berdoa, 2) mempersiapkan siswa untuk belajar dan mengecek kehadiran siswa, 3) guru memperkenalkan materi dan menyampaikan tujuan pembelajaran, 4) memberikan motivasi kepada siswa mengenai pentingnya mempelajari materi luas permukaan balok dan kubus, 5) guru menggali pengetahuan awal siswa dengan cara sebagai berikut: guru memperlihatkan bangun-bangun ruang melalui lembar peraga (kertas gambar). Guru menanyakan kepada siswa: manakah diantara gambar-gambar bangun ruang itu yang merupakan balok? selanjutnya guru melanjutkan pertanyaan sebagai berikut apakah balok itu? bentuk bangun segiempatkah sisi balok? 6) guru membagikan LKS 01 dan alat/bahan yang akan digunakan kapada siswa, 7) guru memberikan penjelasan secukupnya tentang hal-hal yang berkaitan dengan LKS itu, 8) guru meminta siswa masing-masing untuk mengerjakan LKS, 9) guru membimbing dan mamberikan bantuan secukupnya kepada siswa yang mengalami kesulitan dalam mengerjakan LKS, 10) guru mengecek kelompok yang telah ada, 11) guru menyampaikan tujuan diskusi yang akan dilakukan, 12) guru membuka dan memimpin jalannya diskusi, 13) guru memberikan motivasi kepada siswa agar mau mengungkapkan ide-idenya tentang materi yang dikerjakan pada LKS tadi dengan menggunakan bahasanya sendiri, 14) guru memberikan penghargaan (pujian) kepada siswa yang mampu mengungkapkan ide-idenya dengan baik, 15) guru memberikan bantuan secukupnya kepada siswa yang belum mampu untuk mengungkapkan ide-ide geometri dengan menggunakan bahasa yang tepat (baku), 16) guru membagikan LKS dan alat/bahan yang digunakan, 17) guru memberikan penjelasan secukupnya tentang hal-hal yang berkaitan dangan LKS, 18) guru meminta siswa masing- 
masing untuk mengerjakan LKS, 19) guru mengamati siswa dalam mengerjakan LKS dan memberikan bantuan secukupnya apabila diperlukan, 20) guru meminta setiap siswa untuk membuat suatu rangkuman atau ringkasan tentang bagian-bagian balok, 21) guru memberikan bantuan (mendorong dan bimbingan) secukupnya kepada siswa yang mengalami kesulitan dalam merefleksikan pengetahuan geometri bangun ruang yang telah dipelajari fase-fase sebelumnya ke dalam suatu ringkasan dengan menggunakan bahasa yang logis, 22) guru mengumpulkan tugas yang diberikan (ringkasan yang diberikan pada fase 5), 23) guru memberikan tes tertulis kepada siswa untuk melihat pemahaman siswa setelah diadakan kegiatan pembelajaran, 24) guru menutup kegiatan pembelajaran ini. Hasil observasi menunjukkan skor 5 pada aspek 1, 2, 3, 5, 6, 10,11,14, 15, 16, 20, 22, 23; skor 4 pada aspek 4, 7, 8, 9, 12, 13, 17,18, 19, 21, 24; dan aspek 3, 2 dan 1 tidak ada.

Berdasarkan hasil observasi aktivitas guru, diperoleh jumlah skor penilaian aktivitas guru adalah 109. Hal ini berarti taraf aktivitas guru selama pembelajaran berada dalam kategori baik.

Aspek-aspek aktivitas siswa yang diamati meliputi: 1) menjawab salam dan berdoa, 2) mempersiapkan diri untuk mengikuti pembelajaran dan menjawab panggilan guru, 3) memperhatikan penjelasan guru dan memberikan respon terhadap tujuan pembelajaran, 4) memperhatikan penjelaasan guru mengenai pentingnya mempelajari materi luas permukaan balok dan kubus, 5) siswa memperhatikan bangun-bangun ruang yang diperlihatkan oleh guru, 6) siswa menerima LKS dan alat/bahan yang telah dibagikan oleh guru, 7) siswa memperhatikan penjelasan yang disampaikan oleh guru, 8) setiap siswa mengerjakan LKS, 9) bila ada hal-hal yang belum dipahami siswa dalam LKS itu, maka siswa menanyakan atau memintah bimbingan guru, 10) siswa sudah berada dengan kelompoknya, 11) siswa memperhatikan tujuan diskusi yang disampaikan oleh guru, 12) siswa mulai melakukan diskusi tentang materi LKS yang telah diajarkan, 13) siswa mengungkapkan ide-idenya tentang bagian-gagian dari balok (materi LKS ) dengan bahasa sendiri, 14) siswa mendapat penghargaan bila mampu mengungkapkan ide-idenya, 15) pada akhir diskusi siswa bersepakat untuk menyimpulkan tentang bagian-bagian dari balok, 16) siswa menerima LKS dan alat/bahan yang dibagikan oleh guru, 17) siswa memperhatikan penjelasan tentang hal-hal yang berkaitan dengan LKS yang disampaikan guru, 18) masing-masing siswa mulai mengerjakan LKS, 19) siswa memintah bantuan (menanyakan) kepada guru apabila mengalami kesulitan, 20) siswa membuat rangkuman atau ringkasan tentang bagian-bagian dari balok, 21) siswa memintah bantuan secukupnya kepada guru dalam mereflesikan pengetahuan geometri bangun ruang yang diperoleh pada fase-fase sebelumnya kedalam ringkasan yang ditugaskan apabila mengalami suatu kesulitan, 22) menyerahkan tugas yang telah dikerjakan kepada guru, 23) mengerjakan tes tertulis yang diberikan guru, 24) mendengarkan guru.

Hasil observasi aktivitas siswa siklus I, Pengamat 1: aspek nomor 1, 5, 6,7, 8, 10, 14, 16, 17, 18, 20, 22, 23 dan 24 memperoleh nilai 5; aspek nomor 2, 3, 4, 9, 11, 12, 13, 15, 19 dan 21 memperoleh nilai 4. Aktivitas siswa pada siklus I dengan 70 aspek berkategori sangat baik dan 40 aspek berkategori baik. Sehingga dapat disimpulkan aktivitas siswa berdasarkan pengamat 1 pada siklus I masih belum memenuhi kriteria keberhasilan tindakan, karena masih ada 3 aspek yang tidak berada pada kategori baik atau sangat baik. Data selengkapnya dapat dilihat pada Lampiran 29. Pengamat 2: aspek nomor 1, 5, 6, 7, 8, 10, 14, 16, 17, 18, 22, 23 dan 24 memperoleh nilai 5; aspek nomor 2, 3, 4, 9, 11, 12, 13, 15, 19, 20 dan 21 memperoleh nilai 4. Aktivitas siswa pada siklus II dengan 13 aspek berkategori sangat baik, 11 aspek berkategori baik. Sehingga dapat disimpulkan aktivitas siswa pada siklus I 
berdasarkan pengamat 2 masih belum memenuhi kriteria keberhasilan tindakan, karena masih ada 3 aspek yang tidak berada pada kategori baik atau sangat baik.

\section{PEMBAHASAN}

Sebelum pelaksanaan tindakan, peneliti memberikan tes awal kepada siswa yang bertujuan untuk mengetahui pengetahuan prasyarat siswa. Hasil tes awal juga digunakan sebagai pedoman dalam pembentukan kelompok belajar yang heterogen. Hal ini sesuai dengan pendapat Paloloang (2014), bahwa pemberian tes awal sebelum pelaksanaan tindakan bertujuan untuk mengetahui kemampuan siswa pada materi prasyarat dan sebagai pedoman dalam pembentukan kelompok belajar yang heterogen. Pelaksanaan tindakan pada pembelajaran siklus I dan siklus II mengikuti fase-fase model pembelajaran Van Hiele yaitu 1) informasi, 2) orientasi terarah, 3) penjelasan, 4) orientasi bebas, dan 5) integrasi.

Peneliti membuka pembelajaran dengan mengucapkan salam, mengajak siswa untuk berdoa, mengecek kehadiran siswa dan menyiapkan siswa untuk belajar. Kegiatan tersebut bertujuan untuk menarik perhatian siswa di awal pembelajaran. Hal ini sejalan dengan pendapat Amrullah (2014) yang menyatakan bahwa kegiatan guru membuka pembelajaran dengan mengucapkan salam, mengajak siswa untuk berdoa bersama, mengecek kehadiran siswa dan menyiapkan siswa untuk belajar dapat menarik perhatian siswa di awal pembelajaran.

Setelah itu peneliti menyampaikan materi yang dipelajari dan tujuan pembelajaran yang ingin dicapai. Siswa dapat mengetahui materi yang dipelajari dan tujuan pembelajaran yang hendak dicapai sehingga siswa terarah dalam belajar. Hal ini sesuai dengan pendapat Prawiradilaga (2009) bahwa menyampaikan materi dan menjelaskan tujuan pembelajaran sangat diperlukan karena siswa akan terarah dalam mengikuti pembelajaran.

Peneliti memotivasi siswa untuk bersemangat dalam pembelajaran dengan menyampaikan manfaat mempelajari jaring-jaring kubus dan balok. Setelah siswa mengetahui manfaatnya, siswa menjadi termotivasi untuk mengikuti kegiatan pembelajaran. Hal ini sesuai dengan pendapat Wijayanti (2010) bahwa satu diantara cara guru guna membangkitkan motivasi belajar siswa adalah dengan menyampaikan manfaat dari materi yang dipelajari.

Selanjutnya peneliti melakukan apersepsi dengan mengingatkan materi prasyarat kepada siswa. Siswa dapat mengingat kembali dan memahami materi prasyarat sebelum mempelajari materi luas permukaan serta volume balok dan kubus. Hal ini sesuai dengan pendapat Hudojo (1990) yang menyatakan bahwa sebelum mempelajari konsep B, seseorang perlu memahami lebih dulu konsep A yang mendasari konsep B. Sebab tanpa memahami konsep A, tidak mungkin orang itu memahami konsep B.

Kegiatan inti diawali dengan pelaksanaan fase informasi yaitu peneliti menjelaskan secara singkat materi yang akan dipelajari. Selain itu peneliti juga menyampaikan informasi tentang model pembelajaran Van Hiele, sehingga siswa mengetahui fase-fase pembelajaran yang diterapkan dan siswa lebih tertarik mengikuti pembelajaran.

Aktivitas yang dilakukan pada fase orientasi terarah yaitu peneliti mengelompokkan siswa dalam 4 kelompok belajar yang heterogen berdasarkan kemampuan awal siswa. Hal ini sejalan dengan pendapat Susiana (2010) bahwa kelompok kecil yang dibentuk merupakan kelompok yang heterogen, agar timbul interaksi antara siswa sehingga siswa dapat saling bertukar informasi. Selanjutnya peneliti membagikan LKS kepada siswa untuk dikerjakan secara berkelompok. LKS yang dikerjakan siswa akan menuntun mereka agar dapat mengidentifikasi luas permukaan serta volume balok dan kubus. Hal ini sejalan 
dengan pendapat Safrina (2014) bahwa LKS yang disusun sedemikian sehingga siswa secara aktif dirangsang mengeksplorasi objek-objek kajiannya untuk menemukan konsep materi yang dipelajari.

Kegiatan yang dilakukan pada fase uraian yaitu peneliti memilih perwakilan tiap kelompok untuk mempresentasikan hasil kerja kelompoknya, sedangkan kelompok lain bertanya atau menanggapi jawaban yang telah dipresentasikan sehingga hal yang dipelajarinya lebih bermakna. Hal ini sesuai dengan pendapat Rahmawati (2013) yang menyatakan bahwa dalam pembelajaran matematika siswa perlu dibiasakan untuk memberikan argumen atas jawabannya serta memberikan tanggapan atas jawaban yang diberikan oleh orang lain, sehingga apa yang dipelajarinya menjadi bermakna bagi siswa.

Fase orientasi bebas dilakukan peneliti dengan memberikan tugas individu kepada siswa serta berkeliling untuk memantau dan memberikan bimbingan kepada siswa yang mengalami kesulitan. Bimbingan tersebut berupa petunjuk sederhana agar siswa dapat menyelesaikan soal dengan baik. Hal ini sesuai dengan pendapat Purwaningsih (2014) bahwa guru sebagai fasilitator membimbing siswa yang mengalami kesulitan dan bimbingan yang diberikan guru hanya sebagai petunjuk agar siswa bekerja lebih terarah.

Fase integrasi dilakukan peneliti bersama siswa dengan menyimpulkan materi yang telah dipelajari pada siklus I tentang luas permukaan balok dan kubus, sedangkan pada siklus II tentang volume balok dan kubus. Hal ini sesuai dengan pendapat Barlian (2013) yang menyatakan bahwa guru bersama-sama dengan siswa membuat kesimpulan pelajaran pada akhir pembelajaran.

Berdasarkan hasil tes akhir tindakan siklus I, terlihat bahwa siswa sudah mampu menyelesaikan luas permukaan balok dan kubus. Namun masih ada siswa yang melakukan kesalahan. Kesalahan tersebut yaitu siswa belum dapat menyelesaikan pekerjaanya karena belum paham dengan rumus luas permukaan balok dan kubus. Hal ini disebabkan karena siswa tidak bertanya dan siswa kurang teliti dalam menyelesaikan soal. Tetapi secara umum siswa dapat menjawab soal dengan benar. Hal tersebut menunjukkan bahwa siswa dapat menyelesaikan masalah yang berkaitan dengan luas permukaan balok dan kubus dengan benar yang berarti bahwa siswa telah memenuhi indikator keberhasilan tindakan pada pembelajaran siklus I.

Selanjutnya pada tes akhir tindakan siklus II, menunjukkan bahwa siswa dapat menggunakan rumus volume balok dan kubus dan siswa dapat menyelesaikan soal dengan baik. Hal tersebut menunjukkan bahwa siswa dapat menyelesaikan masalah yang berkaitan dengan luas permukaan serta volume balok dan kubus dengan benar yang berarti bahwa siswa telah memenuhi indikator keberhasilan tindakan pada pembelajaran siklus II.

Berdasarkan hasil observasi, aktivitas guru dalam mengelolah pembelajaran pada siklus I berkategori baik dan mengalami peningkatan pada siklus II menjadi berkategori sangat baik. Aktivitas siswa dalam mengikuti pembelajaran pada siklus I berkategori baik dan mengalami peningkatan pada siklus II menjadi berkategori sangat baik.

Berdasarkan hasil dan pembahasan di atas, dapat dikatakan bahwa indikator keberhasilan tindakan telah tercapai dan aktivitas belajar mengalami peningkatan. Peningkatan tersebut diperoleh melalui penerapan model pembelajaran Van Hiele. Oleh karena itu, dapat disimpulkan bahwa penerapan model pembelajaran Van Hiele dapat meningkatkan hasil belajar siswa, khususnya pada materi luas permukaan serta volume balok dan kubus di Kelas VIII SMP Negeri 18 Palu. Hasil penelitian yang diperoleh sejalan dengan penelitian yang dilakukan oleh Yadil (2009) yang menyimpulkan bahwa skenario pembelajaran model Van Hiele yang digunakan dalam pembelajaran pada pokok bangunbangun segiempat dapat meningkatkan pemahaman siswa kelas VII SMP Karuna Dipa Palu 
dari tahap berpikir visualisasi ke tahap berpikir analitik. Hasil penelitian ini juga sejalan yang dilakukan oleh Susanti (2011) yang menyimpulkan bahwa penggunaan model pembelajaran Van Hiele dengan alat peraga efektif digunakan untuk meningkatkan hasil belajar peserta didik pada materi pokok bangun ruang sisi datar kelas VIII MTs Darussalam Kroya. Selanjutnya Sari (2014) menyimpulkan bahwa penerapan model pembelajaran Van Hiele dapat meningkatkan kemampuan siswa dalam memahami sifat-sifat serta unsur-unsur balok dan prisma di SMP negeri 1 Biromaru dengan melakukan penekanan pada tahap informasi, orientasi terarah, penjelasan, orientasi bebas, dan integrasi.

\section{KESIMPULAN}

Berdasarkan hasil dan pembahasan, maka dapat disimpulkan bahwa penerapan model pembelajaran Van Hiele pada pembelajaran luas permukaan serta volume balok dan kubus dapat meningkatkan hasil belajar siswa kelas VIII SMP Negeri 18 Palu mengikuti fase-fase model pembelajaran Van Hiele, yaitu (1) fase informasi, (2) fase orientasi terarah, (3) fase uraian, (4) fase orientasi bebas dan (5) fase integrasi.

Fase informasi, guru mengajukan beberapa pertanyaan terkait luas permukaan serta volume balok dan kubus yang telah dirancang untuk mempelajari pengetahuan awal siswa. Fase orientasi terarah, guru memberikan LKS kepada siswa yang di dalamnya terdapat petunjuk kerja yang akan membantu siswa untuk menemukan rumus luas permukaan serta volume balok dan kubus. Fase uraian, siswa mempresentasikan hasil temuan kelompoknya yang diperoleh pada fase orientasi terarah. Fase orientasi bebas, guru memberikan tugastugas yang lebih kompleks kepada siswa yang dikerjakan secara individu untuk merangsang kreativitas berfikir siswa. Fase integrasi, siswa membuat ringkasan tentang materi yang telag dipelajari pada fase-fase sebelumnya.

Selain itu, hasil belajar yang diperoleh siswa kelas VIII SMP Negeri 18 Palu menunjukan peningkatan dengan menerapkan model pembelajaran Van Hiele pada pembelajaran luas permukaan serta volume balok dan kubus. Peningkatan hasil belajar siswa dapat dilihat dari peningkatan nilai siswa dari siklus I ke siklus II dan juga peningkatan nilai rata-rata siswa yang mengikuti tes akhir dari siklus I ke siklus II. Peningkatan nilai rata-rata siswa yang mengikuti tes akhir dari siklus I ke siklus II yaitu dari $60 \%$ meningkat menjadi $75 \%$.

\section{SARAN}

Beberapa saran yang dapat diajukan kepada guru dari hasil penelitian yang telah dilaksanakan yaitu model pembelajaran Van Hiele dapat menjadi bahan pertimbangan sebagai alternatif dalam memilih model pembelajaran yang dapat meningkatkan hasil belajar siswa pada pelajaran geometri. Bagi calon peneliti selanjutnya, yang ingin menggunakan model pembelajaran Van Hiele perlu memperhatikan pengaturan waktu dan kelas agar proses pembelajaran dapat berjalan sesuai dengan tujuan pembelajaran yang ingin dicapai. 


\section{DAFTAR PUSTAKA}

Amrullah, A. L. (2014). Penerapan Pendekatan Realistic Mathematics Education untuk Meningkatkan Hasil Belajar Siswa pada Materi Soal Cerita Tentang Himpunan di Kelas VII MTsN Palu Barat. Jurnal Electronic Pendidikan Matematika Tadulako. [Online]. Vol. 2(1), 11 halaman. Tersedia: http://jurnal.untad.ac.id/ jurnal/idex.php/JEPMT/article/downdload/3226/2281. [2 april 2018].

Atik,Rina. (2012), Evektivitas Penerapan Model Pembelajaran Van Hiele Terhadap Hasil Belajar Matematika Bagi Siswa Kelas V SD Negeri Bringin 01 Kecamatan Bringinka bupaten Semarang Semester II Tahun Pelajaran 2011/2012. (Online) (http://repository.library.uksw.edu/handle/123456789/849 diakses tanggal 2 April 2018)

Barlian, I. (2013). Begitu Pentingkah Strategi Belajar Mengajar Bagi Guru?. Jurnal Forum Sosial. [Online]. Vol. 6(1), 6 halaman. Tersedia: http://eprints.unsri.ac.id/228/2/ isi.pdf. [20 juni 2018].

Depdikbud. (1999). Penelitian Tindakan (Action Research). Jakarta: Depdikbud Dirjen Pendidikan Dasar dan Menengah.

Depdiknas, (2006). Kurikulum tingkat satuan pendidikan (KTSP) 2006 mata pelajaran metematika. Departemen Pendidikan Nasional

Hudojo, H. (1990). Strategi Mengajar Belajar Matematika. Malang: IKIP Malang.

Julius. (2011). Penerapan Model Pembelajaran Geometri Van Hiele Dalam Membentuk Siswa Membangun Konsep Segitiga. (Online) http:/ /keretamalam1000.wordpress.com/2011/08/06/penerapan-model-pembelajarangeometri-van-hiele-dakam-membantu-siswa-membengun-konsep-segitiga/ diakses tanggal 2 April 2018)

Paloloang, F. B. (2014). Penerapan Model Problem Based Learning untuk Meningkatkan Hasil Belajar Siswa pada Materi Panjang Garis Singgung Persekutuan Dua Lingkaran di Kelas VIII SMP Negeri 19 Palu. Jurnal Elektronik Pendidikan Matematika Tadulako. [Online]. Vol 02 (01), 11 halaman. Tersedia: http://jurnal.untad.ac.id/jurnal/index.php/JEPMT/article/view/3232/2287. [20juni 2018].

Purwaningsih. S. (2014). Penerapan Metode Penemuan Terbimbing untuk Meningkatkan Hasil Belajar Siswa pada Materi Luas Permukaan dan Volume Balok di Kelas VIII SMP Negeri 12 Palu. Skripsi tidak diterbitkan. Palu FKIP Universitas Tadulako.

Prawiradilaga, D. S. (2009). Prinsip Disain Pembelajaran. Jakarta: Kencana.

Rahmawati, F. (2013). Pengaruh Pendekatan Pendidikan Realistik Matematika dalam Meningkatkan Kemampuan Komunikasi Matematis Siswa Sekolah Dasar. Jurnal FMIPA Unila. [Online]. Vol.1(1),14 halaman. Tersedia: http://journal.fmipa.UnIla. ac.id/.index.php/semirata/article/view/882/701. [20 juni 2018]. 
Safrina, K., Ikhsan, M., dan Ahmad, A. (2014). Peningkatan Kemampuan Pemecahan Masalah Geometri melalui Pembelajaran Kooperatif Berbasis Teori Van Hiele. Jurnal Didaktik Matematika. [Online], Vol. 1(1), 11 halaman.Tersedia: http://download.portalgaruda.org/article.php?article=157641\&5828\&title=Peningkat an\%Kemampuan\%20Pemecahan\%20Masalah\%20Geometri\%20melalui\%20Pembela jara n\%20Kooperatif\%20Berbasis\%20Teori\%20Van\%20Hiele. [20 juni 2018].

Sari. DN. (2014). Penerapan Model Pembelajaran Van Hiele untuk Meningkatkan Kemampuan Siswa dalam Memahami Sifat-sifat Serta Unsur-unsur Balok dan Prisma di Kelas VIIIA SMP Negeri 1 Biromaru. Skripsi tidak diterbitkan. Palu FKIP Universitas Tadulako.

Sugiyono. (2007). Memahami Penelitian Kualitatif. Bandung: Alfabeta

Susanti, W. (2011). Efektifitas model pembelajaran Van Hiele dengan alat peraga untuk meningkatkan hasil belajar peserta didik pada materi pokok bangun ruang sisi datar di kelas VII MTs Darussalam Kriya Tahun Pelajaran 2010/2011 [Online]. Tersedia: http://library.walisongo.ac.id/digilib/files/disk 1/109/jtptiain-gdl-wiwisusant-5403-1wiwisus-8.pdf [2 april 2018]

Susiana, E. (2010). IDEAL Problem Solving dalam Pembelajaran Matematika. Jurnal Matematika Kreatif Inovatif. [Online].Vol.1(2),10 halaman. Tersedia: http://journal. unnes.ac.id/nju/index.php/kreano/article/view/1491/1615.[2 april 2018].

Thohari, Khamin. (2010). Meningkatkan Kualitas Pembelajaran Geometri Dengan Teori Van Hiele. [Online]. Tersedia: http://Bdksurabaya.Kemenag.Go.Id/File/Dokumen/ Vanhiele.Pdf [2 april 2018]

Wijayanti, W. (2010). Usaha Guru dalam Meningkatkan Motivasi Belajar Matematika Siswa SMA Negeri 1 Godean. Skripsi FMIPA Universitas Negeri Yogyakarta.[Online].,Tersedia:http://eprints.uny.ac.id/2265/1/WahyuWijayanti06301 244078.[20 juni 2018].

Yadil,M.Nur. (2009). Penerapan Model Pembelajaran Van Hiele Untuk Meningkatkan Pemahaman Siswa SMP Karuna Dipa Palu Terhadap Konsep Bangun-Bangun Segiempat. [Online]. Tersedia: http://eprints.uny.ac.id/ 7015/1/PI-MF.Nur.Yadil.pdf [2 april 2018] 